\title{
The Importance of Service Quality in Building Customer Satisfaction and Loyalty in the Service Industry: A Case Study of Hunky Dory Barbershop
}

\author{
Muhammad Fakhrul Arifin ${ }^{1 *}$; Hartoyo²; Eva Z. Yusuf ${ }^{3}$ \\ ${ }^{1,2}$ School of Business, Magister Management, Institut Pertanian Bogor University \\ Jln. Raya Pajajaran, Bogor 16128, Indonesia \\ ${ }^{3}$ PT Myriad Research \\ Jln. Tanah Abang Timur No. 5, Jakarta Pusat 10250, Indonesia \\ 1fakhrularifin293@gmail.com; hartoyo@ipb.ac.id; 3eva.yusuf@myriad-research.com
}

Received: $1^{\text {st }}$ February 2020/ Revised: $9^{\text {th }}$ March 2020/ Accepted: $10^{\text {th }}$ March 2020

How to Cite: Arifin, M. F., Hartoyo, \& Yusuf. E. Z. (2020). The Importance of Service Quality in Building Customer Satisfaction and Loyalty in the Service Industry: A Case Study of Hunky Dory Barbershop. Binus Business Review, 11(2), 79-89. https://doi.org/10.21512/bbr.v11i2.6268

\begin{abstract}
The research aimed to see how the influence of service quality was on customer satisfaction and loyalty in Hunky Dory Barbershop. The research was an explanatory research. The sampling technique was done by giving questionnaires to random customers who came to Hunky Dory barbershop. Analysis applied Structural Equation Modeling-Partial Least Square (SEM-PLS) to see the relationship between variables of service quality, price perception, trust, customer satisfaction, and loyalty. The results show that all variables affect customer satisfaction and loyalty, except price perception. It does not affect satisfaction since customers do not consider price when they are satisfied with the service. There is a significant positive relationship between service quality and loyalty which shows that the higher the service quality is, the higher the loyalty will be.
\end{abstract}

Keywords: service quality, customer satisfaction, customer loyalty

\section{INTRODUCTION}

Business in the service sector relies on the trust of customers, it focuses on the service quality provided to the customers. The increasingly fierce business competition requires business people always to innovate. Barbershop is a business carried out by men of all ages. Barber services have spread throughout Indonesia. Currently, there is a modern barber service in urban areas called barbershop.

Barbershop is an innovation or development of fashion. In the past, the business of barbershop starts from a barber under a tree to a permanent one which is often called Madura haircut. All of the haircut business models are proven to exist and get segmented customers (Yudiatma \& Triastity, 2016). Barbershop offers not only regular haircut services, but also additional services such as cream bath, hair coloring, and massage. Then, barbershop also sells several types of equipment so that men can appear more tidy and greasy. Although barbershop has a higher price compared to a general barber, it has already had its market. Barbershop's target market is men from the middle to the upper class.

Barbershop is included in the Micro, Small, and Medium Enterprises (MSME) category according to the provisions of the Law of the Republic of Indonesia Number 20 of 2008. In this law, asset values ranging from 50 to 500 million are classified as small business scale. Barbershop is included in the category of having assets around 50 to 500 million based on asset of Hunky Dory. The development of barbershop in Indonesia is fairly rapid. According to data from the Indonesia Barbershop Association (IBA) in 2016 (Indonesia Investments, 2017), there were 4000-5000 Barbershops scattered in Indonesia. In 2017, there was a 20-30 percent increase in the number of barbershops in Indonesia.

Data from the economic census conducted in 2016 showed that Bogor had the largest number of 
MSMEs registered. Barbershop contributed to the increasing number of MSMEs in Bogor. From the same data, it was also found that barbershop was categorized as other services with the total of 181.916 throughout West Java. The number accounted for $3,96 \%$ of MSMEs in West Java (Badan Pusat Statistik (BPS), 2017).

In Bogor, there are several Barbershop choices. One of them is Hunky Dory Barbershop. It was established in 2014 and a pioneer barbershop with premium quality and service. There are several other advantages in this barbershop, such as qualified tools, barbers who have years of experience in doing haircuts and been certified, as well as the right price with the services obtained. Hunky Dory Barbershop also opens a franchise with two investment package options, namely in Jabodetabek with an investment of Rp300 million and outside Jabodetabek with an investment of Rp310 million. Now, Hunky Dory Barbershop has 11 branches (Hunky Dory, 2018).

Based on Hunky Dory (2018), there was a significant decrease in subscribers in the final quarter of 2018 with the sharpest decline in September 2018. It was $58,2 \%$ with 61 customers compared to August 2018 with 146 customers. The expansion of the barbershop in Bogor causes business-level competition. Business competition in the barbershop requires business people to conduct evaluations and innovations at all times. Thus, it can provide the best quality of service and experience. Moreover, it can still retain customers who come as well as those who are just trying. Based on the service quality provided or at the post-consumption stage, customers will determine whether they are satisfied or not and whether they are loyal or not.

Service is an action or activity that can be offered by one party to another party. It is intangible and does not result in any ownership. All services are carried out to provide a sense of satisfaction desired by customers (Kotler \& Keller, 2016). According to Tjiptono (2004), service quality is conformity, compatibility, and meeting customer needs from the beginning and at any time. The service quality must be considered, and it becomes the most important point in a business engaged in services.

Service quality dimensions (SERVQUAL) is developed by Parasuraman, Zeithaml, and Malhotra (2005). It includes reliability, responsiveness, assurance, empathy, and tangibles used as a strategic planning step by a service company. According to Tjiptono (2004), the SERVQUAL model emphasizes the importance of customer expectations before buying or consuming a service as a standard or reference in evaluating the performance of the service concerned. Setyanta (2017) studied a barbershop in Yogyakarta. After taking the survey and testing it by Structural Equation Modeling (SEM), the researcher showed that the perception of quality, perceived fairness of price, and comfort had a positive effect on customer satisfaction.

Similarly, Beneke, Hayworth, Hobson, and Mia
(2012) said the same thing. There was a relationship between service quality and customer satisfaction. The dimensions of service quality that influenced satisfaction the most were physical appearance and personal interaction (empathy).

Then, customer trust is formed in customers because they feel very satisfied with the product or service provided. The trust that is built by the customers develops satisfaction for them. With high trust, the customers will make a repeat transaction of the service or product received by them (Dabholkar \& Sheng, 2012). Coelho and Henseler (2012) concluded that the higher the customers' trust was, the stronger the satisfaction, and loyalty would.

After customers use a product or service, they will feel satisfied or dissatisfied. It also determines whether they will repurchase the product or service. This dimension is called loyalty. Sukamto and Lumintan (2015) analyzed the effect of customer satisfaction on loyalty. The results had a significant impact on satisfaction and loyalty.

Then, Bahrudin and Zuhro (2016), who examined Samsung Android, showed a significant positive relationship between customers' trust and loyalty. The analytical tool used was multiple regression. Moreover, El-Manstrly, Kandampully, and Duddy (2016) concluded that trust was perceived as integrity, honesty, and competence. In their research, some results proved the influence of trust on loyalty. Then, Lee, Lee, and Tan (2015) revealed in their research on online business, that there was a positive influence between trust and loyalty in online businesses.

The differences in the research with the previous research are in the aims. The research aims to find the correlation between trust to loyalty, so the connection from satisfaction to loyalty is through the trust. The hypothesis of decreasing customers is the increasing price and other competitors. The researchers assume that despite weaknesses in the third quarter of 2018, Hunky Dory Barbershop can sustain its business by forming new management strategies so that repeat purchases will occur by customers. The formation of a new strategy can increase the number of customers and get maximum profits.

The object of the research is barbershop because this industrial sector has a good prospect in business development. The purpose of the research is to see how the influence of service quality is on customer satisfaction and loyalty in Hunky Dory Barbershop based on the background of the problems. It is to find out why the number of customers is decreased and solutions to make customers loyal and satisfied.

\section{METHODS}

The research applies a quantitative-explanatory research. The purpose of choosing explanatory methods is because the researchers want to explain the relationship between variables of service quality, customer satisfaction, and loyalty through hypothesis 
testing. The data source is primary data. The analysis of the relationship of service quality, price perceptions, and trust and satisfaction and loyalty is conducted using SEM analysis with Partial Least Square (PLS). PLS is a type of SEM that is a component-based with formative construct properties. There are several other approaches to SEM. The first approach is the widely applied Covariance based SEM (CB-SEM) by using software packages such as AMOS, EQS, LISREL, and M-Plus. The second approach is PLS focusing on the analysis of variance. It can be done by using PLS-Graph, Visual-PLS, Smart-PLS, and Warp-PLS (Kumar \& Purani, 2018).

According to Ghozali and Latan (2012), PLS is an SEM equation model, namely statistical modeling techniques that are a combination of principal component analysis, regression analysis, and path analysis. Test using PLS makes it possible for researchers to model structural equations with relatively small sample sizes, and there is no need for normal multivariate assumptions.
The data used are obtained by distributing questionnaires directly and randomly to customers who have used services at Hunky Dory Barbershop in Bogor. The participants are accompanied in filling out the questionnaires. Hair, Ringle, and Sarstedt (2011) suggested that the minimum sample size was 100 by considering models with five or fewer constructs, each with more than three items with high item commonalities. This suggestion provides a rough idea of the sample size for the research. It is generally regarded that 100 is the minimum practical size for using SEM. In the research, there are 34 indicators, so the minimum sample taken is 170 . The researchers will use 210 samples to be examined. The scaling technique used is a Likert scale using a scale of 1-5. Taherdoost (2016) explained that the Likert scale was good for a question with several answer choices related to the agreement. The sequences strongly agree (5), agree (4), neutral (3), disagree (2), and strongly disagree (1).

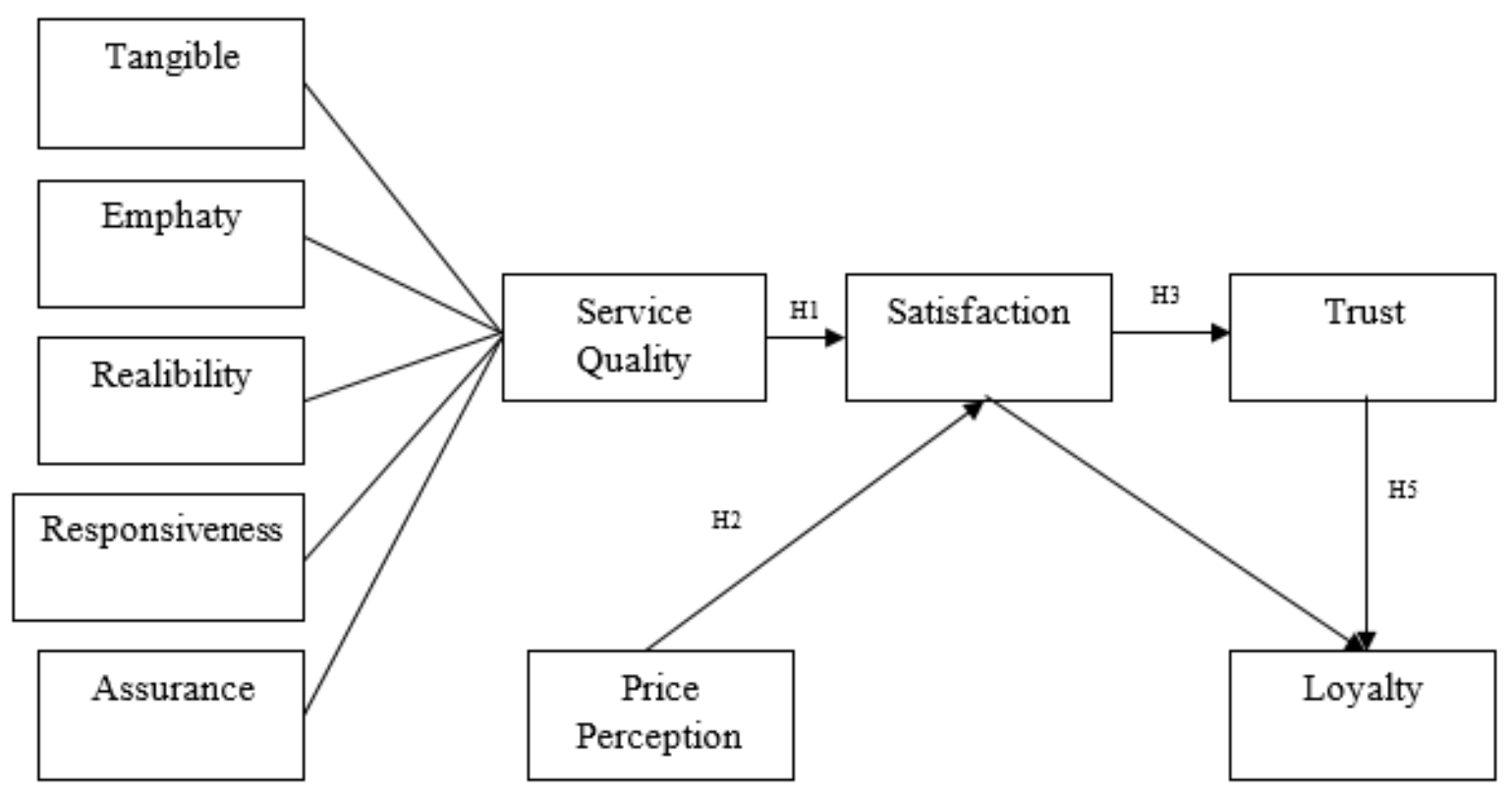

Figure 1 Research Hypotheses

Moreover, the hypotheses formed in the research (see Figure 1) are as follows:

H1: there is a positive relationship between service quality and customer satisfaction

$\mathrm{H} 2$ : there is a positive relationship between price perception and customer satisfaction

H3: perceived customer satisfaction is positively associated with perceived trust

$\mathrm{H} 4$ : there is a positive relationship between customer satisfaction and customer loyalty

H5: there is a positive relationship between trust and customer loyalty 
The variables used are service quality, price perception, trust, satisfaction, and loyalty. Service quality consists of five dimensions, namely, tangible, reliability, responsiveness, assurance, and empathy.
Based on these variables, parameters or indicators that represent the influence of each variable are needed. Those are explained in Table 1 and Figure 2.

Table 1 Research Variables and Indicators

\begin{tabular}{|c|c|c|}
\hline Variable & Indicator code & Indicator \\
\hline \multirow[t]{3}{*}{ Service quality } & $\mathrm{X} 1$ & Barbershop has good lighting \\
\hline & $\mathrm{X} 2$ & Barbershop has an adequate parking lot \\
\hline & X3 & Barbershop has attractive colors \\
\hline \multirow[t]{4}{*}{ Tangible } & $\mathrm{X} 4$ & Barbershop plays comfortable songs \\
\hline & $\mathrm{X} 5$ & The atmosphere of the barbershop feels comfortable \\
\hline & $\mathrm{X} 6$ & Barbershop is clean \\
\hline & $\mathrm{X} 7$ & The employees' appearance is neat \\
\hline \multirow[t]{4}{*}{ Reliability } & X9 & The chair for the haircut is comfortable \\
\hline & $\mathrm{X} 10$ & Employees are accurate in handling equipment \\
\hline & X11 & Barber can provide haircuts by following customers' requests \\
\hline & $\mathrm{X} 12$ & Service is as promised \\
\hline \multirow[t]{5}{*}{ Responsiveness } & $\mathrm{X} 13$ & Employees quickly deal with customer problems \\
\hline & $\mathrm{X} 14$ & Employees can solve problems faced by customers \\
\hline & $\mathrm{X} 15$ & Employees are swift in fulfilling customers' desires \\
\hline & $\mathrm{X} 16$ & $\begin{array}{l}\text { Employees can answer customers' questions related to the products and } \\
\text { services offered }\end{array}$ \\
\hline & $\mathrm{X} 17$ & Employees quickly handle customers' complaints \\
\hline \multirow[t]{4}{*}{ Assurance } & $\mathrm{X} 18$ & Employees' knowledge \\
\hline & X19 & Service procedures for customers \\
\hline & $\mathrm{X} 20$ & Barber communication with customers \\
\hline & $\mathrm{X} 21$ & Quality assurance of service \\
\hline \multirow[t]{4}{*}{ Empathy } & $\mathrm{X} 22$ & Employees pay attention to customers \\
\hline & $\mathrm{X} 23$ & Barber cares about customer satisfaction regarding the haircut \\
\hline & $\mathrm{X} 24$ & Friendliness in serving customers \\
\hline & $\mathrm{X} 25$ & The services provided are good to customers \\
\hline \multirow[t]{2}{*}{ Price Perception } & $\mathrm{X} 26$ & The price of services is affordable for me \\
\hline & $\mathrm{X} 27$ & Price matches with what customers get \\
\hline \multirow[t]{2}{*}{ Trust } & $\mathrm{X} 28$ & Customers are willing to entrust the barber \\
\hline & X29 & Barber is a professional \\
\hline \multirow[t]{3}{*}{$\begin{array}{l}\text { Customer } \\
\text { satisfaction }\end{array}$} & $\mathrm{Y} 1$ & $\begin{array}{l}\text { Based on all my experiences at this barbershop, I feel satisfied with the } \\
\text { service provided }\end{array}$ \\
\hline & Y2 & Satisfied with the selection \\
\hline & $\mathrm{Y} 3$ & My overall rating of this barbershop's service is very good \\
\hline \multirow[t]{5}{*}{ Customer loyalty } & Y4 & Say good things about this barbershop to others \\
\hline & Y5 & Recommend this barbershop to other parties who ask me \\
\hline & Y6 & Suggest my friends or family to use the services of this barbershop \\
\hline & Y7 & Making this barbershop as my first choice in cutting hair \\
\hline & Y8 & Buy other services at this barbershop in the future \\
\hline
\end{tabular}




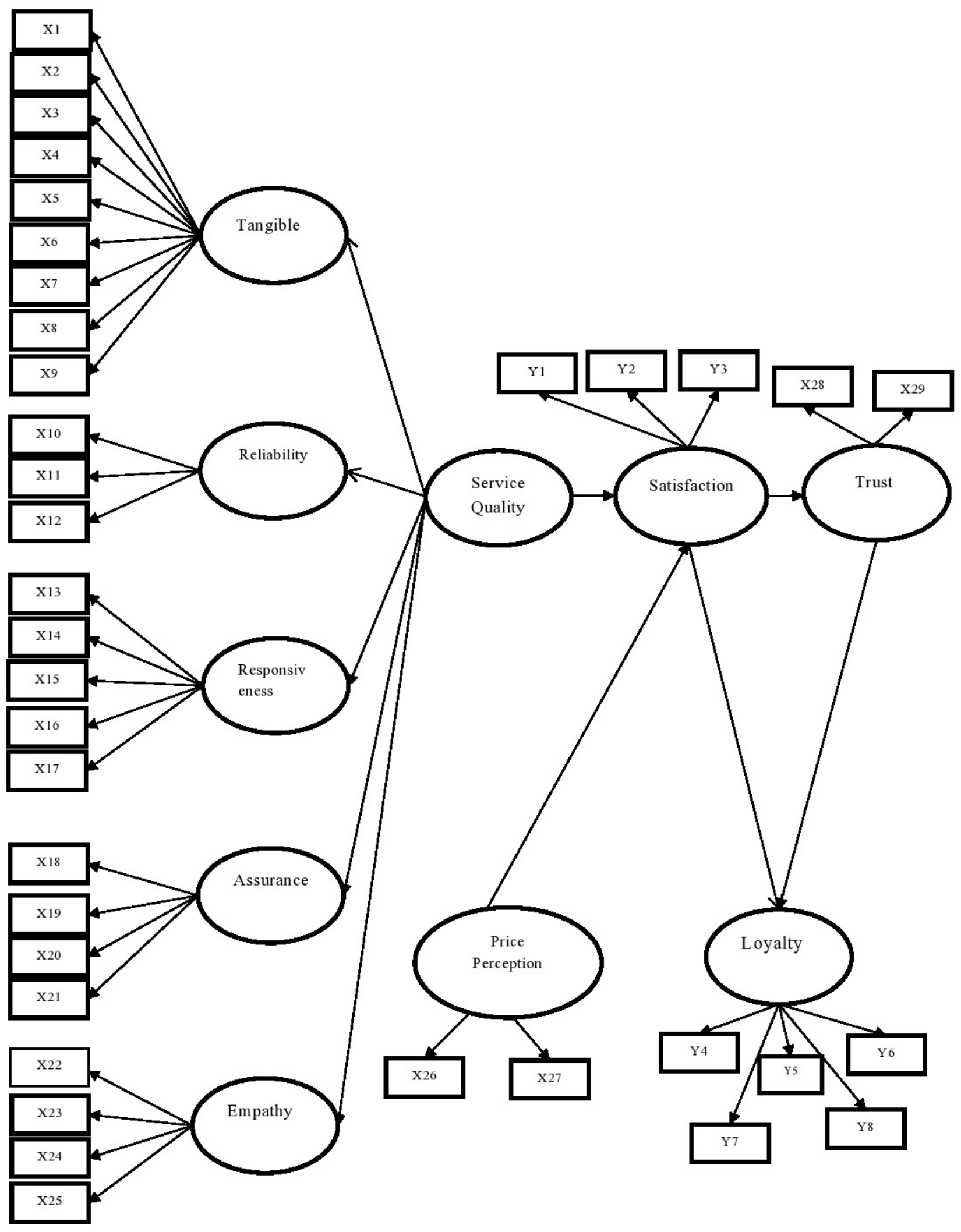

Figure 2 SEM Research Model 


\section{RESULTS AND DISCUSSIONS}

The conceptualization and measurement of service quality become a central issue in services marketing research (Annamdevula \& Bellamkonda, 2016). The instrument for data collection is a questionnaire constructed with previously validated scales. Around 210 customers take part in the research.

According to Ghozali and Latan (2012), there are three criteria in using analysis techniques with Smart-PLS, namely convergent validity, discriminant validity, and composite reliability. In the research, 34 indicators of 5 variables are used. The validity test can be seen from the loading factor value for each construct indicator (Knekta, Runyon, \& Eddy, 2019). The loading factor values $>0,55$ can be said to be valid and has t-value above 1,96 (Meyer, Van Witteloostuijn, \& Beugelsdijk, 2017). The validity test results show that eight indicators are declared invalid (loading factor value $<0,55$ ), as seen in Table 2 and Figure 3. The invalid eight indicators are excluded from the model. The process of issuing indicators is called the dropping process. Indicators that are considered invalid come from the tangible (5), responsiveness (1), assurance (1), and empathy (1). After dropping those, all indicators have a loading factor $>0,55$ (valid). It shows that all indicators have represented other variables.

Table 2 Outer Loadings value

\begin{tabular}{|c|c|c|c|c|c|}
\hline Indicators & $\begin{array}{c}\text { Value of Loading } \\
\text { Factor }\end{array}$ & Result & Indicators & $\begin{array}{c}\text { Value of Loading } \\
\text { Factor }\end{array}$ & Result \\
\hline $\mathrm{X} 1$ & 0,52 & Not Valid & $\mathrm{X} 24 \mathrm{a}$ & 0,76 & Valid \\
\hline $\mathrm{X} 2$ & 0,51 & Not Valid & $\mathrm{X} 24 \mathrm{~b}$ & 0,72 & Valid \\
\hline $\mathrm{X} 3$ & 0,52 & Not Valid & $\mathrm{X} 25 \mathrm{a}$ & 0,68 & Valid \\
\hline $\mathrm{X} 4$ & 0,46 & Not Valid & $\mathrm{X} 25 \mathrm{~b}$ & 0,73 & Valid \\
\hline $\mathrm{X} 5$ & 0,68 & Valid & $\mathrm{X} 26$ & 0,71 & Valid \\
\hline X6 & 0,53 & Not Valid & $\mathrm{X} 27 \mathrm{a}$ & 0,63 & Valid \\
\hline $\mathrm{X} 7$ & 0,71 & Valid & $\mathrm{X} 27 \mathrm{~b}$ & 0,79 & Valid \\
\hline $\mathrm{X} 8$ & 0,67 & Valid & $\mathrm{X} 27 \mathrm{c}$ & 0,76 & Valid \\
\hline X9 & 0,86 & Valid & $\mathrm{X} 27 \mathrm{~d}$ & 0,71 & Valid \\
\hline $\mathrm{X} 10 \mathrm{a}$ & 0,73 & Valid & $\mathrm{X} 28 \mathrm{a}$ & 0,85 & Valid \\
\hline $\mathrm{X} 10 \mathrm{~b}$ & 0,57 & Valid & $\mathrm{X} 28 \mathrm{a}$ & 0,61 & Valid \\
\hline X11 & 0,76 & Valid & $\mathrm{X} 29 \mathrm{a}$ & 0,81 & Valid \\
\hline $\mathrm{X} 12 \mathrm{a}$ & 0,81 & Valid & $\mathrm{X} 29 \mathrm{~b}$ & 0,81 & Valid \\
\hline $\mathrm{X} 12 \mathrm{~b}$ & 0,72 & Valid & Y1 & 0,81 & Valid \\
\hline $\mathrm{X} 13$ & 0,72 & Valid & Y2a & 0,63 & Valid \\
\hline X14 & 0,54 & Not Valid & $\mathrm{Y} 2 \mathrm{~b}$ & 0,81 & Valid \\
\hline $\mathrm{X} 15$ & 0,75 & Valid & $\mathrm{Y} 2 \mathrm{c}$ & 0,81 & Valid \\
\hline $\mathrm{X} 16$ & 0,76 & Valid & Y3 & 0,81 & Valid \\
\hline $\mathrm{X} 17$ & 0,73 & Valid & Y4 & 0,69 & Valid \\
\hline $\mathrm{X} 18 \mathrm{a}$ & 0,68 & Valid & Y5 & 0,66 & Valid \\
\hline $\mathrm{X} 18 \mathrm{~b}$ & 0,57 & Valid & Y6 & 0,74 & Valid \\
\hline $\mathrm{X} 18 \mathrm{c}$ & 0,74 & Valid & Y7 & 0,83 & Valid \\
\hline X19 & 0,77 & Valid & Y8 & 0,77 & Valid \\
\hline $\mathrm{X} 20$ & 0,69 & Valid & & & \\
\hline $\mathrm{X} 21$ & 0,54 & Not Valid & & & \\
\hline $\mathrm{X} 22 \mathrm{a}$ & 0,72 & Valid & & & \\
\hline $\mathrm{X} 22 \mathrm{~b}$ & 0,51 & Not Valid & & & \\
\hline $\mathrm{X} 23$ & 0,73 & Valid & & & \\
\hline
\end{tabular}


The convergent validity test looks at the value of the square root of Average Variance Extracted (AVE) Meanwhile, the composite reliability and cross-loading are to see the discriminant validity. The evaluation of the measurement model using the root of AVE is by comparing the value of the AVE root with the correlation between constructs. If the value of the root of AVE is higher than the value of the correlation between constructs, good discriminant validity is achieved (over than 0,5 is highly recommended) (Taber, 2018). The results of AVE value over $0,5 \mathrm{imply}$ that the indicators on each latent variable contribute more than $50 \%$. The results of the analysis are shown in Table 3. The AVE value of each latent variable has a value $>0,5$. It means that the PLS model meets the requirements for good convergent validity.
Table 3 AVE Value

\begin{tabular}{lcc}
\hline Variable & AVE & Composite Reliability \\
\hline Assurance & 0,511 & 0,838 \\
Empathy & 0,545 & 0,878 \\
Trust & 0,608 & 0,859 \\
Satisfaction & 0,606 & 0,884 \\
Loyalty & 0,553 & 0,910 \\
Price Perception & 0,525 & 0,860 \\
Reliability & 0,606 & 0,846 \\
Responsiveness & 0,574 & 0,861 \\
Tangible & 0,609 & 0,843 \\
\hline
\end{tabular}

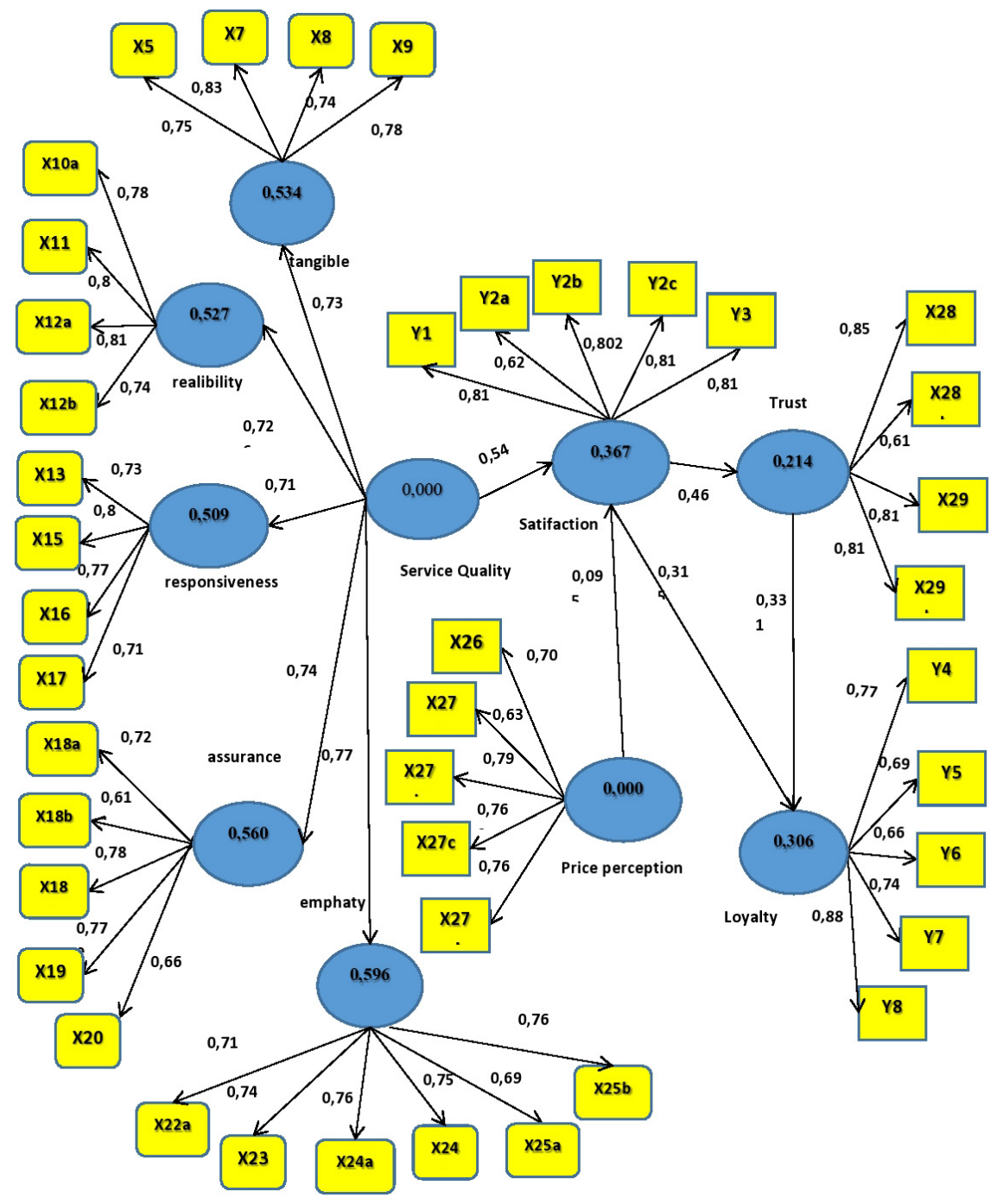

Figure 3 SEM-PLS Measurement Model 
The next test is the reliability of the model. It is to prove how the value of the accuracy, consistency, and accuracy of the instruments are in measuring construct values in Table 3. Hair et al. (2011) explained that reliability could be measured by using the composite reliability output with the condition that the value had to be above 0,7. Similarly, Taber (2018) stated that an indicator was reliable if the value of Cronbach alpha and composite reliability had more than value of 0,6 , and 0,7 respectively. The results based on Table 3 have a composite reliability value of more than 0,7 . These values suggest acceptable levels of internal consistency, consequently, and reliability. Then, the responses obtained for each scale are averaged to provide an overall score for the construct of interest. These results indicate that all latent constructs have good, accurate, and consistent reliability values because they meet the requirements. Thus, the model has good reliability value.

The first evaluation of the inner model can be seen from the value of R-square or the coefficient of determination. R-square values for the trust variable are 0,213 . It shows that the indicators of the variables in the model can explain the variable by $21,3 \%$, while the remaining $78,7 \%$ is explained by other factors that are not in the model. Next, the satisfaction variable has an R-square value of 0,367 . The result indicates that the variables indicators in the model can explain the satisfaction variable around $36,7 \%$. However, the rest is explained by other factors that are not in the model. Similarly, in loyalty variable, R-square value is 0,305 . It shows that indicators of the variables in the model can explain the variable by $30,5 \%$. The remaining $69,5 \%$ is explained by other indicators that are not shown in the model. The results are in Table 4.

Table 4 R-Square Value

\begin{tabular}{lc}
\hline Variable & R-square \\
\hline Service quality & 0 \\
Price perception & 0 \\
Trust & 0,213 \\
Satisfaction & 0,367 \\
Loyalty & 0,305 \\
\hline
\end{tabular}

Next, the structural models connect exogenous latent variables with endogenous latent variables or the relationship of endogenous variables with other endogenous variables. In the research, the model related to the proposed research hypotheses requires a causal relationship between latent variables. Hypothesis test uses t-test statistics to see whether the hypothesis is accepted or rejected. The research hypotheses can be accepted if t-value (t-statistics) is higher than t-table at an error rate $(\alpha)$ of $5 \%$ which is 1,96 . The coefficient value shows a positive or negative difference. Table
5 shows the path coefficient values (original sample estimates) and the calculated t-value (t-statistics) in the inner model.

Table 5 Bootstrapping Results

\begin{tabular}{lcc}
\hline $\begin{array}{l}\text { Relationship between } \\
\text { Variables }\end{array}$ & Estimation & T-Value \\
\hline $\begin{array}{l}\text { Service Quality and } \\
\text { Satisfaction }\end{array}$ & 0,546 & 6,111 \\
$\begin{array}{l}\text { Price Perception and } \\
\text { Satisfaction }\end{array}$ & 0,094 & 0,919 \\
Satisfaction and Trust & 0,462 & 5,696 \\
Satisfaction and Loyalty & 0,468 & 5,962 \\
Trust and Loyalty & 0,331 & 3,846 \\
\hline
\end{tabular}

Service quality is one of the key factors influencing customers' purchase decisions. It increases customer satisfaction, tangible physical environment, and price perception. Those are essential elements in determining the level of customer satisfaction and playing a role in enhancing customer loyalty (Jiang \& Zhang, 2016). Service quality significantly influences customer satisfaction (Na-Nan, Sanamthong, \& Sulong, 2016). The results of the H1 test show that the calculated t-value is $6,111>$ t-table $(1,960)$. The results of this test indicate that $\mathrm{H} 1$ is accepted. From the test results, it obtains an estimated coefficient value of 0,546 . It means that the higher the service quality is provided, the higher the customer satisfaction will increase by $54,6 \%$. These results are in line with Tarinda and Zaini (2018), Setyanta (2017), Jamal and Evanita (2019), and Farooq, Salam, Fayolle, Jaafar, and Ayupp (2018).

Then, $\mathrm{H} 2$ test shows that price perception does not directly influence satisfaction. The results of the t-statistics test support the statement. It is found that the $\mathrm{t}$ - value is $0,919<1,960$. It indicates that $\mathrm{H} 2$ is rejected. There is no significant effect between price perception and satisfaction. This result is supported by Rivai and Wahyudi (2017) and Harjati and Venesia (2015).

Customer satisfaction is an emotional reaction to the difference between what customers expect and what they receive. Knowing what makes a customer satisfy can help the company improve the quality of products and services (Nugraheni \& Fauziah, 2019). Satisfaction has a direct effect on trust. The results show the t-value is 5,696. It proves that $\mathrm{H} 3$ is accepted. The test results also obtained an estimated coefficient value of 0,462 , indicating that the higher the level of customer satisfaction, the trust will increase by $46,2 \%$. The results are supported by Alsajjan (2014), Iglesias, Markovic, and Rialp (2019), and Leninkumar (2017).

In $\mathrm{H} 4$, $\mathrm{t}$-value is 5,962. It shows that satisfaction directly affects loyalty. Thus, H4 is accepted. The 
estimation value shows that if satisfaction value increases, it affects the loyalty about $46,8 \%$. The results are in line with Kurniawan and Shihab (2015), Sukamto and Lumintan (2015), and Stathopoulou and Balabanis (2016). The results reflect the current situation in Hunky Dory Barbershop. Customers are satisfied with the service quality. Thus, a satisfied customer will be loyal and trusting.

According to the commitment-trust theory, trust is the degree of confidence in an exchange partner's reliability and integrity. Such confidence leads customers to repurchase and reuse services or products from a company that they trust. Trust also has positive effects on customer loyalty (Park, Kim, \& Kwon, 2017). Trust influences loyalty with t-value of 3,846 . The result is in line with Bahrudin and Zuhro (2015), and El-Manstrly et al. (2016).

Moreover, hairdressing services differ from other retailing sector services with the former perceived as greater involvement in the purchase decision in experience quality and intangibility. The prices of hairdressing services are difficult to comprehend as these services cannot be kept, demonstrated, returned, or resold. Furthermore, the experience of customers with the service that they receive in the hairdressing salon is intangible. Thus, it cannot be sold or transferred to a third party (López-Jáuregui, MartosPartal, \& Labeaga, 2019).

The hairdressing industry has evolved into a very competitive industry in both developed and developing economies. So, it has a substantial impact on the economy (Eresia-Eke, Jammine, \& Locke, 2019). In the service industry, service reliability is directly related to customer loyalty (Njeru, Cheruiyot, \& Maru, 2019). Customer loyalty has been widely associated with an organization's financial performance because it plays a keys role in maintaining and increasing sales. More importantly, loyalty contributes to customer attractiveness and increase profits because the cost of attracting new customers is at least five times higher than the cost of maintaining existing ones (Izogo, 2017).

Customer satisfaction decisions are reached by comparing the performance of a product or service with the customers' expectations (Kotler \& Keller, 2016). Customer satisfaction will encourage customer loyalty that should be considered by Hunky Dory Barbershop. The higher the service quality is, the higher customer satisfaction will be (Sofiana \& Prihandono, 2019). Customer satisfaction gets the company's attention in developing service strategies, so it should be the primary goal.

\section{CONCLUSIONS}

From the result, it can be concluded that there is a relationship between perceived service quality, customer satisfaction, trust, and customer loyalty. The findings show that if customers perceive high service quality or the perceived service value is high, it will correspond with high customer satisfaction. Besides, the results also imply that high customer satisfaction is correlated with customer loyalty in the barbershop studied. In this case, especially as it concerns the service quality, Hunky Dory Barbershop should consider training the employees, create a more professional and conducive environment, and emphasize the increasing current levels of responsiveness, empathy, reliability, assurance, and physical evidence. Practically, it can be achieved by providing high-quality services at affordable prices.

The implication for the research is Hunky Dory Barbershop needs to maintain the customers that have already engaged with a barber. Hunky Dory Barbershop should try to make some loyalty points or loyalty cards for the customer and give rewards or discounts. The research limitation is on the number of customers, and there are still other variables that make it possible to influence customer satisfaction and loyalty. Future research in this field can examine a larger geographical area and a larger group of respondents using probability sampling techniques. While the research focuses solely on the correlation between trust and loyalty and between price perception and satisfaction, future research can assess the importance of service customization in the presence of other relationships of marketing instruments.

\section{REFERENCES}

Alsajjan, B. A. (2014). Satisfaction-trust model: Developing customer satisfaction and trust indices for mobile service providers in the UK. International Review of Management and Business Research, 3(2), 10881104.

Annamdevula, S., \& Bellamkonda, R. S. (2016). The effects of service quality on student loyalty: The mediating role of student satisfaction. Journal of Modelling in Management, 11(2), 446-462.

Badan Pusat Statistik (BPS). (2017). Hasil pendaftaran (listing) usaha atau perusahaan sensus ekonomi 2016 Provinsi Jawa Barat. Retrieved from https://www.bps.go.id/publication/2017/12/25/ ad1459ca2768ac4f5dd938d9/hasil-pendaftaranusaha-perusahaan-sensus-ekonomi-2016-provinsijawa-barat.html

Bahrudin, M., \& Zuhro, S. (2015). Pengaruh kepercayaan dan kepuasan pelanggan terhadap loyalitas pelanggan. BISNIS: Jurnal Bisnis dan Manajemen Islam, 3(1), 1-17.

Beneke, J., Hayworth, C., Hobson, R., \& Mia, Z. (2012). Examining the effect of retail service quality dimensions on customer satisfaction and loyalty: The case of the supermarket shopper. Acta Commercii, 12(1), 27-43.

Coelho, P. S., \& Henseler, J. (2012). Creating customer loyalty through service customization. European Journal of Marketing, 46(3/4), 331-356.

Dabholkar, P. A., \& Sheng, X. (2012). Consumer participation in using online recommendation 
agents: Effects on satisfaction, trust, and purchase intentions. The Service Industries Journal, 32(9), 1433-1449.

El-Manstrly, D., Kandampully, J., \& Duddy, R. (2016). Enhancing customer loyalty: Critical switching cost factors. Journal of Service Management, 27(2), 1-45.

Eresia-Eke, C. E., Jammine, C., \& Locke, C. (2019). Towards customer satisfaction and loyalty: What cuts it in a hair salon? The Southern African Journal of Entrepreneurship and Small Business Management, 11(1), 1-7.

Farooq, M. S., Salam, M., Fayolle, A., Jaafar, N., \& Ayupp, K. (2018). Impact of service quality on customer satisfaction in Malaysia airlines: A PLS-SEM approach. Journal of Air Transport Management, 67(March), 169-180.

Ghozali, I., \& Latan, H. (2012). Partial Least Square: Konsep, Teknik dan Aplikasi Smart PLS 2.0 M3. Semarang: Badan Penerbit Universitas Diponegoro.

Hair, J. F., Ringle, C. M., \& Sarstedt, M. (2011). PLS-SEM: Indeed a silver bullet. Journal of Marketing Theory and Practice, 19(2), 139-152.

Harjati, L., \& Venesia, Y. (2015). Pengaruh kualitas layanan dan persepsi harga terhadap kepuasan pelanggan pada maskapai penerbangan Tiger Air Mandala. E-Journal Widya Ekonomika, 1(1), 64-74.

Hunky Dory. (2018). Laporan kegiatan dan keuangan Hunky Dory tahun 2019. Bogor: Hunky Dory.

Iglesias, O., Markovic, S., \& Rialp, J. (2019). How does sensory brand experience influence brand equity? Considering the roles of customer satisfaction, customer affective commitment, and employee empathy. Journal of Business Research, 96(March), 343-354.

Indonesia Investments. (2017). Booming creative businesses in Indonesia: Barbershop (hair salon). Retrieved from https://www.indonesia-investments. com/id/news/todays-headlines/booming-creativebusinesses-in-indonesia-barbershop-hair-salon/ item 8054

Izogo, E. E. (2017). Customer loyalty in telecom service sector: The role of service quality and customer commitment. The TQM Journal, 29(1), 19-36.

Jamal, M., \& Evanita, S. (2019). The effect of satisfaction on service quality and promotion toward client loyalty of Integrated Service Unit-Animal Health Center (UPT-Puskeswan) and Artificial Insemination (IB) in Pariaman City. In Third Padang International Conference On Economics Education, Economics, Business and Management, Accounting and Entrepreneurship (PICEEBA 2019).

Jiang, H., \& Zhang, Y. (2016). An investigation of service quality, customer satisfaction and loyalty in China's airline market. Journal of Air Transport Management, 57(October), 80-88.

Knekta, E., Runyon, C., \& Eddy, S. (2019). One size doesn't fit all: Using factor analysis to gather validity evidence when using surveys in your research. CBE-Life Sciences Education, 18(1), 1-17.

Kotler, P., \& Keller, K. L. (2016). Marketing management (15 $5^{\text {th }}$ ed.). England: Pearson Education Limited.
Kumar, D. S., \& Purani, K. (2018). Model specification issues in PLS-SEM: Illustrating linear and non-linear models in hospitality services context. Journal of Hospitality and Tourism Technology, 9(3), 338-353.

Kurniawan, I., \& Shihab, M. S. (2015). Pengaruh nilai nasabah, kualitas pelayanan, dan kualitas hubungan terhadap kepuasan nasabah serta implikasinya terhadap loyalitas nasabah Bank Syariah Mandiri. Jurnal Manajemen dan Bisnis Sriwijaya, 13(2), 199216.

Lee, J., Lee, J. N., \& Tan, B. C. (2015). Antecedents of cognitive trust and affective distrust and their mediating roles in building customer loyalty. Information Systems Frontiers, 17(1), 159-175.

Leninkumar, V. (2017). The relationship between customer satisfaction and customer trust on customer loyalty. International Journal of Academic Research in Business and Social Sciences, 7(4), 450-465.

López-Jáuregui, Á., Martos-Partal, M., \& Labeaga, J. M. (2019). Impact of SMEs strategy on loyalty: The hairdresser case. Spanish Journal of MarketingESIC, 23(2), 273-293.

Meyer, K. E., Van Witteloostuijn, A., \& Beugelsdijk, S. (2017). What's in a p? Reassessing best practices for conducting and reporting hypothesis-testing research. Journal of International Business Studies, 48, 535-551.

Na-Nan, K., Sanamthong, E., \& Sulong, M. (2016). Employees engagement, quality of service and customers satisfaction affecting customer loyalty of hair and beauty salon business. International Journal of Applied Business and Economic Research, 13(15), 3409-3421.

Njeru, L. M., Cheruiyot, T. K., \& Maru, L. (2019). Effect of service quality on customer loyalty in selected African Airlines. Economic Research, 3(10), 1-19.

Nugraheni, P., \& Fauziah, L. (2019). The impact of corporate governance on customer satisfaction and loyalty of Islamic insurance company in Indonesia. Journal of Accounting and Investment, 20(2), 114-128.

Parasuraman, A., Zeithaml, V. A., \& Malhotra, A. (2005). ES-QUAL: A multiple-item scale for assessing electronic service quality. Journal of Service Research, 7(3), 213-233.

Park, E., Kim, K. J., \& Kwon, S. J. (2017). Corporate social responsibility as a determinant of consumer loyalty: An examination of ethical standard, satisfaction, and trust. Journal of Business Research, 76(July), 8-13.

Rivai, A. R., \& Wahyudi, T. A. (2017). Pengaruh persepsi kualitas, citra merek, persepsi harga terhadap loyalitas pelanggan dengan kepercayaan dan kepuasan pelanggan sebagai variabel mediasi. Jurnal Bisnis dan Komunikasi, 4(1), 29-37.

Setyanta, B. (2017). Anteseden dan konsekuensi dari kepuasan pelanggan: Survei kepuasan pelanggan barbershop di Yogyakarta. Al Tijarah, 3(1), 29-44.

Sofiana, H., \& Prihandono, D. (2019). Customer satisfaction as the mediating influence of service recovery, perceived quality, and price fairness on Indihome triple play services to customer loyalty. Management Analysis Journal, 9(3), 275-283. 
Stathopoulou, A., \& Balabanis, G. (2016). The effects of loyalty programs on customer satisfaction, trust, and loyalty toward high-and low-end fashion retailers. Journal of Business Research, 69(12), 5801-5808.

Sukamto, R., \& Lumintan, D. (2015). The impact of marketing mix towards customer loyalty mediated by customer satisfaction of Blackberry Indonesia. iBuss Management, 3(2), 316-324.

Taber, K. S. (2018). The use of Cronbach's alpha when developing and reporting research instruments in science education. Research in Science Education, 48(6), 1273-1296.

Taherdoost, H. (2016). Measurement and scaling techniques in research methodology; survey/questionnaire development. International Journal of Academic Research in Management (IJARM), 6(1), 1-5.

Tarinda, R., \& Zaini, A. (2018). Pengaruh lokasi dan kualitas pelayanan terhadap kepuasan pelanggan pada Scissors Barbershop Malang. Jurnal Aplikasi Bisnis, 4(1), 89-92.

Tjiptono, F. (2004). Prinsip-prinsip total quality service. Yogyakarta: Andi.

Yudiatma, F., \& Triastity, R. (2016). Pengaruh kualitas pelayanan terhadap kepuasan konsumen Arfa Barbershop di Surakarta. Jurnal Ekonomi dan Kewirausahaan, 15(3), 346-353. 